Article

\title{
Grass Canopy Architecture Influences Temperature Exposure at Soil Surface
}

\author{
Xiulin Gao *(i) and Dylan W. Schwilk \\ Department of Biological Science, Texas Tech University, Lubbock, TX 79409, USA; dylan.schwilk@ttu.edu \\ * Correspondence: xiulin.gao@ttu.edu; Tel.: +1-806-445-4865
}

Received: 29 June 2018; Accepted: 22 September 2018; Published: 26 September 2018

check for updates

\begin{abstract}
There is increasing recognition that plant traits contribute to variations in fire behavior and fire regime. Diversity across species in litter flammability and canopy flammability has been documented in many woody plants. Grasses, however, are often considered homogeneous fuels in which any flammability differences across species are attributable to biomass differences alone and therefore are of less ecological interest, because biomass is hugely plastic. We examined the effect of grass canopy architecture on flammability across eight grass species in short grass steppe of New Mexico and Texas. To characterize grass canopy architecture, we measured biomass density and "biomass-height ratio" (the ratio of canopy biomass above $10 \mathrm{~cm}$ to that of biomass below $10 \mathrm{~cm}$ ). Indoor flammability experiments were performed on air-dried individual plants. As expected, plant biomass influenced all flammability measures. However, biomass-height ratio had additional negative effect on temperature exposure at soil surface (accumulation of mean temperature $>100{ }^{\circ} \mathrm{C}$ ) in well-cured grasses, which is an important fire behavior metric predicting soil heating and meristem survival. This canopy architecture effect, however, needs further investigation to be isolated from biomass density due to correlation of these two traits. This result demonstrates the potential for species-specific variation in architecture to influence local fire effects in grasses.
\end{abstract}

Keywords: grass flammability; canopy architecture; soil heating; meristem survival; grass fire ecological impact

\section{Introduction}

Savannas, in which grasses coexist with scattered trees, are fire-dependent ecosystems: Recurrent fires suppress tree density and maintain high light environments favorable to grasses. Grasses provide fine, dead biomass that feeds recurrent fires, which are characterized by rapid rate of spread and short residence time [1,2]. Such fires often result in little soil heating and therefore allow high survival of surface and below-ground grass meristems [3,4]. However, such fires limit woody plants, because they can kill or top kill woody plants. Although the role of fine grass fuels in suppressing woody savanna plants has been well established [5-7], there has been less attention paid to how variation in grass flammability traits may alter fire behavior, which in turn can affect damage to grasses themselves, as well as change the ecological impact of grass fire on trees.

Plants vary in flammability through variation in their functional traits, but identification of such traits has been better developed for woody fuels than for grass fuels. Identified flammability traits include biomass, fuel moisture content, leaf dimensions, and chemical composition, and traits that characterize plant canopy architecture such as biomass density and retention of dead biomass [8-16]. Whether grasses vary in flammability in response to trait variation, however, is still in dispute. Some argue that grass fires are largely driven by total above-ground biomass [17-19]. Plant aboveground biomass, however, is hugely plastic and, although there are species differences, biomass is largely determined by environmental factors such as precipitation and herbivory. Such plasticity 
implies potentially weak species or ecotypic flammability effects. On the other hand, some grass flammability studies found that although total biomass had a strong effect on flammability, plant traits including leaf surface area to volume ratio and canopy architecture (biomass density) also influenced grass flammability $[20,21]$. However, canopy architecture has only been examined on partial plant canopies [21], which may not fully represent species variation in architectural traits.

Fire induced tree mortality is a complex process that involves both biotic and abiotic factors, but an important effect of fire is tissue necrosis caused by exposure of plant cells to lethal temperature, which can eventually lead to tree mortality through killing vegetative buds, the vascular meristem, or roots and rhizomes [22-26]. Another direct impact of fire is xylem dysfunction and cavitation, which also can cause tree mortality by reducing xylem conductivity [27-29]. Tree-killing fire characteristics include fire intensity (measured by proxies such as maximum flame height and mass loss rate, which predict canopy scorch [30,31]), total heat release near lower tree canopy (measured by fire duration or an integration of temperature or heat flux over time which predict canopy and bole tissue necrosis [32,33]), and heating near the soil surface (measured by integrated temperature or organic matter loss, which predicts root, stolon, and rhizome injury [22,34]). Therefore, interspecies variations in grass flammability traits that could influence below-ground and/or above-ground heating have the potential to alter fire effects on trees.

Flammability is not a single axis of variation but is multidimensional [35,36]. Thus far, evidence suggests that most variation occurs along two axes, a total heat release or duration of heating axis, and an axis representing the rate of heat release. This view, however, is most strongly supported by leaf litter flammability studies in which fuel load was standardized [37-39]. Each axis potentially has distinct effects on tree mortality: "total heat release" (rarely measured directly but often inferred from proxies such as biomass consumption or temperature integration over time) at different heights relative to ground determines temperature exposure in important tree organs, while the rate of heat release (usually measured as flame spread rate) influences fire extent and tree crown damage in part due to its effect on flame heights. Biomass density can influence aeration and heat transfer during fire. However, the direction of biomass density effect on flammability is fuel type dependent [35]: It positively influenced fire intensity (measured as either rate of spread or maximum biomass-loss rate) in canopy fuel and grass fuel and negatively influenced the rate of spread in litter fuel $[21,37,40,41]$. Another potentially important architectural trait is the relative distribution of biomass in relation to height above the soil surface: Grass species vary in where biomass is held, and this could influence relative heating near the surface versus heating at greater heights above the soil. Surface heating can damage grass meristems at and below the soil surface, as well as damage tree roots. Heat release at higher locations above soil surface should have a greater impact on shrub and tree crown damage.

We assessed the flammability of eight grass species of the short-grass steppes in northeastern New Mexico and in northern Texas, USA and examined how canopy architecture influenced putative tree-killing flammability measurements after accounting for any effect of total above-ground biomass. Our overall interest is tree-grass interaction via fires in savannas, therefore, in addition to consumability [42] (the amount of fuel combusted which represents total heat release in a single experiment if we assume heat content of plant tissue remained constant), we also measured putative tree-killing fire characteristics including maximum flame height, duration of heating, and temperature integration above $100{ }^{\circ} \mathrm{C}$ near canopy (at $10 \mathrm{~cm}, 20 \mathrm{~cm}$, and $40 \mathrm{~cm}$ height relative to the ground, the mean temperature of these three above-ground temperature measurements was used to summarize canopy temperatures) and at the soil surface. In addition to examining grass biomass density as a canopy trait, we defined another simple canopy architectural trait: the biomass-height ratio (the ratio of biomass above $10 \mathrm{~cm}$ plant height to the biomass below $10 \mathrm{~cm}$ plant height).

We asked two questions: (1) How does total biomass influence flammability? (2) Does grass canopy architecture influence putative tree-killing flammability measurements after we account for an effect of total biomass? Given the importance of fuel load found in previous studies [17,21,43], we expect that total above-ground biomass should have positive effects on all flammability components, 
especially on total heat release. We then tested for additional effects of canopy architecture on flammability measurements. We expected biomass-height ratio to decrease the surface cumulative temperature and heating duration, because less biomass is available near the ground, but to increase these measures in the canopy. We expected biomass density to positively influence fire intensity measures, because porous grass fuel is well aerated; therefore, heat transfer will be faster when biomass is more densely packed.

\section{Materials and Methods}

All species studied are found in the southern Great Plains and were collected from short grass steppe of Kiowa National Grassland; northeastern New Mexico between 1400 1900 m elevation; and Lyndon B. Johnson National Grassland, northern Texas between 270 310 m elevation, USA. The study areas are dominated by $\mathrm{C} 4$ grasses with scattered trees. Juniperus monosperma (Engelm.) Sargent, Pinus edulis Engelm, and Pinus ponderosa Lawson \& C. Lawson are the most common tree species in the Kiowa National Grassland. Woody species in the Lyndon B. Johnson National Grassland are more diverse with the dominant families including the Fagaceae, Cupressaceae, and Salicaceae.

Plant samples were collected during summer (early June-early August) 2016 from eight grass species: Aristida purpurea Nutt., Bromus inermis Leyss., Chasmanthium latifolium (Michx.) Yates, Eragrostis curvula (Schrad.) Nees, Elymus elymoides (Raf.) Swezey, Hesperostipa neomexicana (Thurb. ex J.M. Coult.) Barkworth, and Panicum anceps Michx., Pascopyrum smithii (Rydb.) Á. Löve. We chose these species at random from all species present at the study region with typical canopy cover rates greater than 10\%. All but Eragrostis curvula are native species. Most are tussock grasses (i.e., bunchgrasses), but Bromus inermis and Pascopyrum smithii are more sod-forming species. Because biomass-height ratio is a destructive measurement, we collected samples in pairs so that both measurement groups had a balanced and wide range of plant sizes within each species. Within a pair, the two plants were within $3 \mathrm{~m}$ of one another and distinct pairs (samples) were separated by a minimum distance of $30 \mathrm{~m}$. For sod-forming grasses, we increased this distance to $100 \mathrm{~m}$ to avoid multiple pairs from the same clone. We collected 8-15 pairs for each species. Plants were unearthed carefully to minimize damage of plant architecture, labeled, and stored in collection bags. Geographic location was logged for each sample using a GPS device. We then transported samples back to Texas Tech University and dried them at $32{ }^{\circ} \mathrm{C}$ for 3 days in a sample drying room to standardize fuel moisture.

Before the burning experiment, we measured plant height, the number of tillers, and width at the base and top of each plant including inflorescences. We measured biomass-height ratio for the member of each pair designated not to be burned by cutting plants into two sections at $10 \mathrm{~cm}$ plant height and weighing each section (soil surface to $10 \mathrm{~cm}$ section and above $10 \mathrm{~cm}$ section). To obtain biomass-height ratio for the burned individuals, we built a linear model with data collected from the unburned individuals. This model included the biomass above $10 \mathrm{~cm}$ as a dependent factor and species, tiller number, and total biomass as predictors. We then predicted biomass above $10 \mathrm{~cm}$ for the burned individuals. With total biomass and predicted biomass above $10 \mathrm{~cm}$, we were able to estimate biomass below $10 \mathrm{~cm}$ for the burned plants. Adjusted $\mathrm{R}^{2}$ was 0.98 for the above $10 \mathrm{~cm}$ biomass prediction model. Biomass-height ratio was expressed as the ratio of biomass above $10 \mathrm{~cm}$ plant height to biomass below $10 \mathrm{~cm}$. Biomass density was calculated by dividing total above-ground biomass by plant volume, and we treated the grass canopy as a truncated cone for the volume calculation.

We performed indoor burning experiments at the Lubbock Fire Department in a cement building. This structure allowed full control of wind and partial control of temperature and relative humidity. Due to constraints on sample collection (we had to collect different species at different times to avoid collecting immature plants) and limited sample storage space, our flammability experiments were not fully blocked by day, but we maximized the number of species on each burning day and each species was burned on 2-3 different days except $A$. purpurea (in total we had 7 different trial dates across June through early August). Before each burn, we recorded air temperature and relative humidity with a Kestrel 3000 pocket weather meter (Nielsen-Kellerman, Co., Chester, PA, USA). 
Because most burning trials did not last longer than 10 minutes, we assumed that there was little fluctuation in temperature or relative humidity during a single trial. Means and standard deviations of measured air temperature and relative humidity before each burning trial across experiment dates were $31.0^{\circ} \mathrm{C}, 2.1{ }^{\circ} \mathrm{C}$ and $42.5 \%, 5.6 \%$. We sampled 3-5 burned individuals of each species by taking a $5 \mathrm{~g}$ subsample from each including both leaf and culm to measure fuel moisture content and recorded initial weight of the sample (including the pot and soil) immediately before the burn trial. Figure 1 depicts the instrumentation for the burning trials. We ignited each plant at the base by first igniting a cotton ball (about $0.6 \mathrm{~g}$ each) to which $1 \mathrm{~mL}$ of $50 \%$ ethanol solution was added and then placing the burning cotton ball at the plant base. We removed the cotton ball immediately once ignition occurred. To characterize flammability, we measured maximum flame height $(\mathrm{cm}$, visually assessed by using a ruler as a reference). We also measured flame temperature every second at four heights: the soil surface (two replicates of each reading), at $10 \mathrm{~cm}$, at $20 \mathrm{~cm}$, and at $40 \mathrm{~cm}$ above the soil surface $\left({ }^{\circ} \mathrm{C}\right.$, read by $\mathrm{K}$ type thermocouple temperature sensors with $0.8 \mathrm{~mm}$ diameter, Omega Engineering, INC, Norwalk CT). We measured combustion over time by recording the sample biomass every second (g) on a balance (with $0.01 \mathrm{~g}$ readability) via a connected laptop. After each burn, the final weight of the pot, soil, and residual plant material was recorded before the residual biomass (charred material, ash, and any unburned biomass) was removed. Then, we removed the residual above-ground biomass and weighed the pot again (pot, soil, and below-ground biomass).

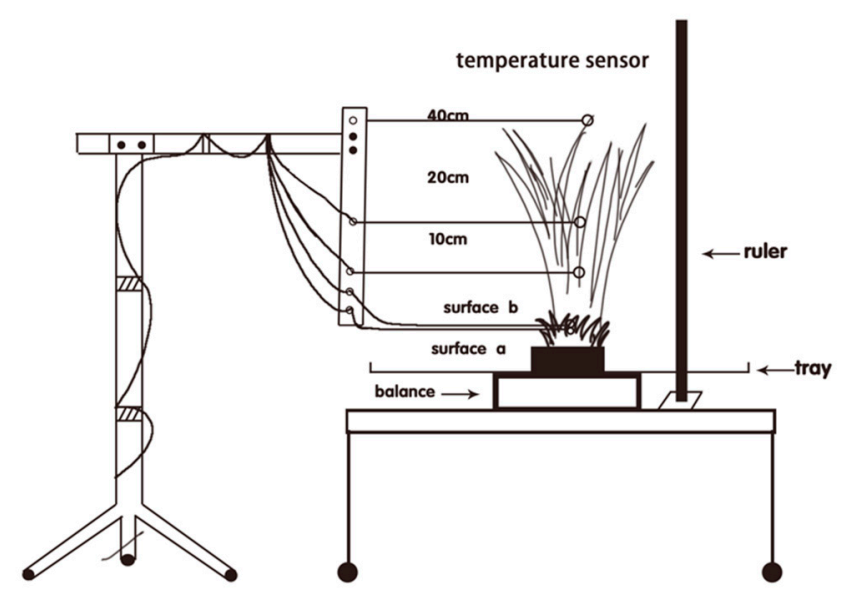

Figure 1. Experimental apparatus for flammability experiments. Temperature was read every second at soil surface (locations a \& b), $10 \mathrm{~cm}, 20 \mathrm{~cm}$, and $40 \mathrm{~cm}$ relative to ground by k-type thermocouple temperature sensors that were placed at the center of plant. A metal ruler was placed by the plant as a reference for maximum flame height assessment. A cardboard tray caught biomass that fell during combustion. The balance was connected to a computer to record every second during combustion (code at https:/ / github.com/schwilklab/serial-balance).

All data analysis was conducted in R [44]. We fit a negative exponential model predicting remaining biomass as a function of time for each trial and extracted the coefficient, $\lambda$, as maximum biomass-loss rate when $p$-value for fitted coefficient was less than 0.01 . This parameter represents the rate of heat release (fire intensity) if we assume similar tissue specific heat content across all species $[45,46]$. Duration of heating at soil surface was calculated as the period during which mean temperature of soil surface was above $100{ }^{\circ} \mathrm{C}$. Cumulative temperature to which plant tissues were exposed at the soil surface was calculated as "temperature integration", which corresponded to the sum of the mean temperatures over every second during the same period $\left({ }^{\circ} \mathrm{C} \cdot \mathrm{s}\right)$. Past studies have shown that this measurement correlates well with the "heat release" axis of flammability and is generally independent of flame-spread rate [37,39]. We calculated duration of heating and temperature integration for the canopy-height temperature sensors as well. Because we measured temperature at multiple locations above the soil $(10 \mathrm{~cm}, 20 \mathrm{~cm}$, and $40 \mathrm{~cm})$ and these measurements were 
highly correlated, to control experiment-wide error rates, we averaged all above-ground temperature measurements at each second when summarizing temperature at canopy level. We labeled the canopy measurements according to their average height and refer to "duration of heating at $25 \mathrm{~cm}^{\prime \prime}$ and "temperature integration at $25 \mathrm{~cm}$ " hereafter for simplicity. We used total mass consumed to represent total heat release during a single flammability experiment (based on the assumption that tissue-specific heat content is similar across all grass species $[45,46])$.

Although results from litter flammability studies suggested that total heat release and rate of heat release, which are our putative tree-killing fire characteristics, are two independent axes of flammability variation [37-39], it is not clear if and how they covary in grasses, especially when prior experiments controlled for fuel load while we specifically did not in order to examine direct effects of above-ground biomass. To deal with collinearity, we conducted principal component analysis (PCA) on four tree-killing flammability measurements (duration of heating, temperature integration, maximum mass-loss rate, and total mass combusted) to guide data selection for further analysis. We did not include maximum flame height in our PCA, because this measurement showed a strong non-linear saturation relationship when compared with other proxies for fire intensity.

The fuel load effect on fire behavior is better established than are architectural effects $[17,21,43]$ but is of less interest to us; therefore, we used a residuals-based approach to preserve power to investigate potential architectural effects. First, we built linear models with total biomass as the only predictor for each of the flammability measurements. One observation of E. curvula had extreme high total biomass. To avoid bias, we conducted analyses with and without this observation and obtained the same conclusion. We then used the resulting biomass-corrected flammability (residuals of first model) for further analysis investigating canopy architecture effects on flammability. To explore whether and how biomass density and biomass-height ratio influenced flammability, we built linear mixed models based on first principles with R package "lme4" [47]. We standardized all predictors to be mean-centered with unit standard deviation to make the effect sizes of each predictor comparable. We included both canopy traits and their interaction as predictors and biomass-corrected flammability as the dependent variable. We included relative humidity as a main effect covariate but not air temperature, because these two predictors were tightly correlated, and daily variation in relative humidity was larger than variation in that across different trial dates. In addition, including either air temperature or humidity did not change our conclusion. Species was a random effect in our models. To choose between random intercept-only models and those with a random slope term by species as well, we did a single selection step as recommended by Zuur [48]. We included species as a random intercept term and then compared the resulting model fit to a model, which included the same fixed effects but with a term for random slopes by species for each architecture trait and chose the model that had the lowest Akaike Information Criterion [49]. We examined the significance of fixed effects using the "mixed" function from the "afex" package in R [50]. To avoid unacceptable Type 1 error rates during the calculation of approximate degrees of freedom and $p$-values, we used the Kenward-Roger approximation [51], which is suggested by Luke [52]. Data and code are available at https://github.com/XiulinGao/Grass-Flammability.

\section{Results}

Principal component analysis indicated that the first two axes account for $87.0 \%$ of total variation in flammability metrics (Figure 2). The first axis mainly captured duration and total heat release with high loadings for total mass loss, duration above $100{ }^{\circ} \mathrm{C}$, and temperature integration. The second axis represented rate of heat release, with maximum mass-loss rate having the highest loading value. We chose temperature integration at soil surface and $25 \mathrm{~cm}$, and maximum mass-loss rate, as dependent variables for further analysis, as these were the highest loading variables on each axis. 


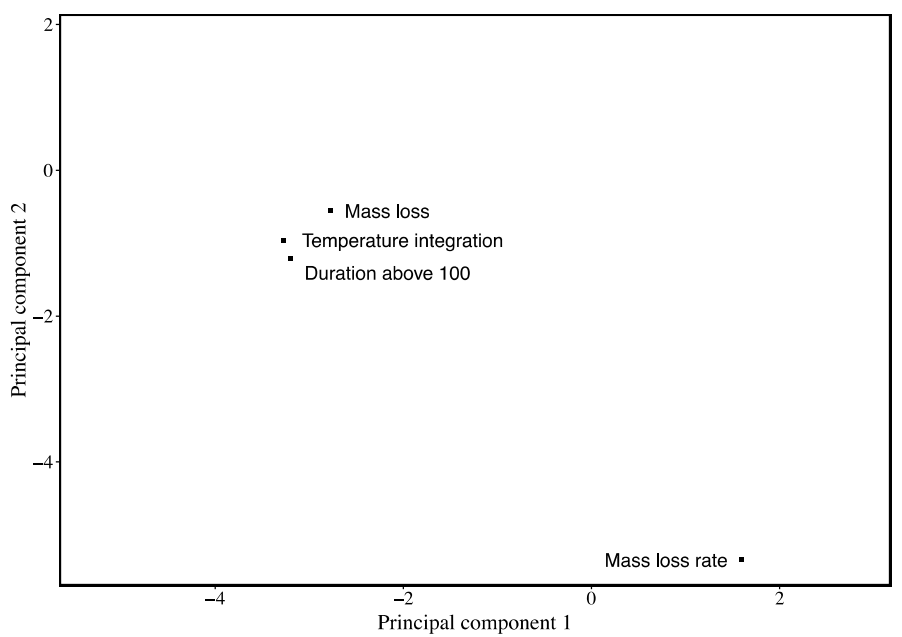

Figure 2. Principal component analysis biplot of flammability measurements. Flammability measurements include duration of heating above $100{ }^{\circ} \mathrm{C}$ at $25 \mathrm{~cm}$, temperature integration above $100{ }^{\circ} \mathrm{C}$ at $25 \mathrm{~cm}$, total mass combusted, and maximum mass-loss rate. The first two axes account for $87.0 \%$ of total variance.

Total above-ground biomass had a strong positive linear effect on temperature integration above $100{ }^{\circ} \mathrm{C}$ at the soil surface and at $25 \mathrm{~cm}$ (Figure 3). Adjusted $\mathrm{R}^{2}$ for the model of temperature integration at soil surface was $0.58(p<0.0001)$ and for the model of temperature integration at $25 \mathrm{~cm}$ was 0.59 $(p<0.0001)$. We then examined if grass canopy architecture influenced biomass-corrected temperature integration at the two locations and found an additional effect of canopy architecture on flammability (Figure 4). Biomass-height ratio had a negative linear effect on temperature integration at soil surface (Table $1, p=0.038$ ). Neither biomass density nor relative humidity had additional effects on temperature integration at either location.

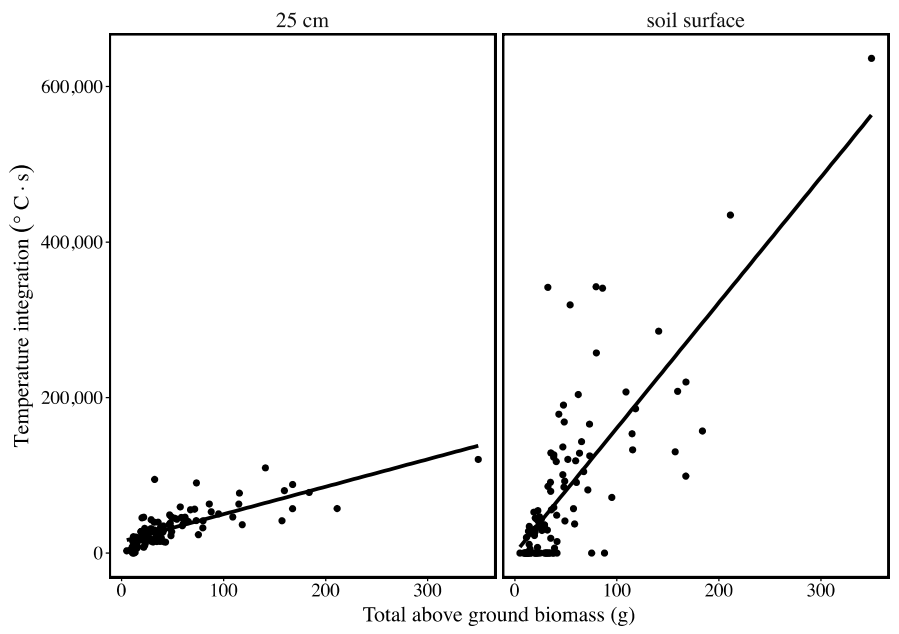

Figure 3. Relationship between total above-ground biomass and temperature integration above $100{ }^{\circ} \mathrm{C}$ at soil surface and $25 \mathrm{~cm}$. Lines indicate the best fit linear models (soil surface: $p<0.0001$, adjusted $\mathrm{R}^{2}=0.58 ; 25 \mathrm{~cm}: p<0.0001$, and adjusted $\mathrm{R}^{2}=0.59$ ). 


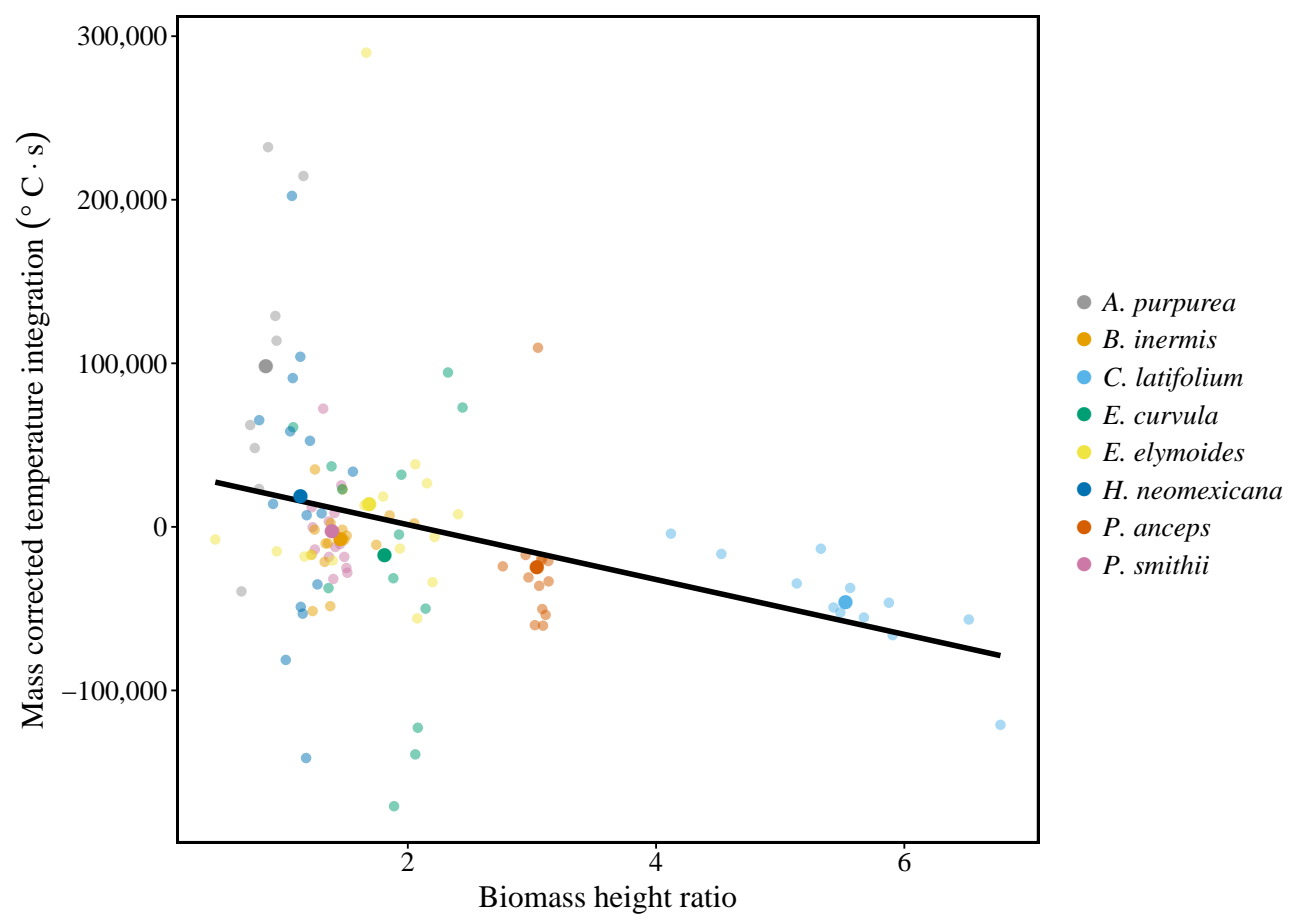

Figure 4. Relationship between biomass-height ratio and biomass-corrected temperature integration above $100{ }^{\circ} \mathrm{C}$ at soil surface across eight grass species. The line indicates the best fitted linear mixed model with species as random intercept effect $(p=0.038)$. Small points in background are individual observations, and large points are species means.

Total above-ground biomass had a weak negative linear effect on maximum mass-loss rate (Figure 5, $p=0.02$, adjusted $\mathrm{R}^{2}=0.04$ ). We did not find any additional effect of grass architecture or relative humidity on maximum mass-loss rate. Architecture trait and flammability means are listed in Table 2.

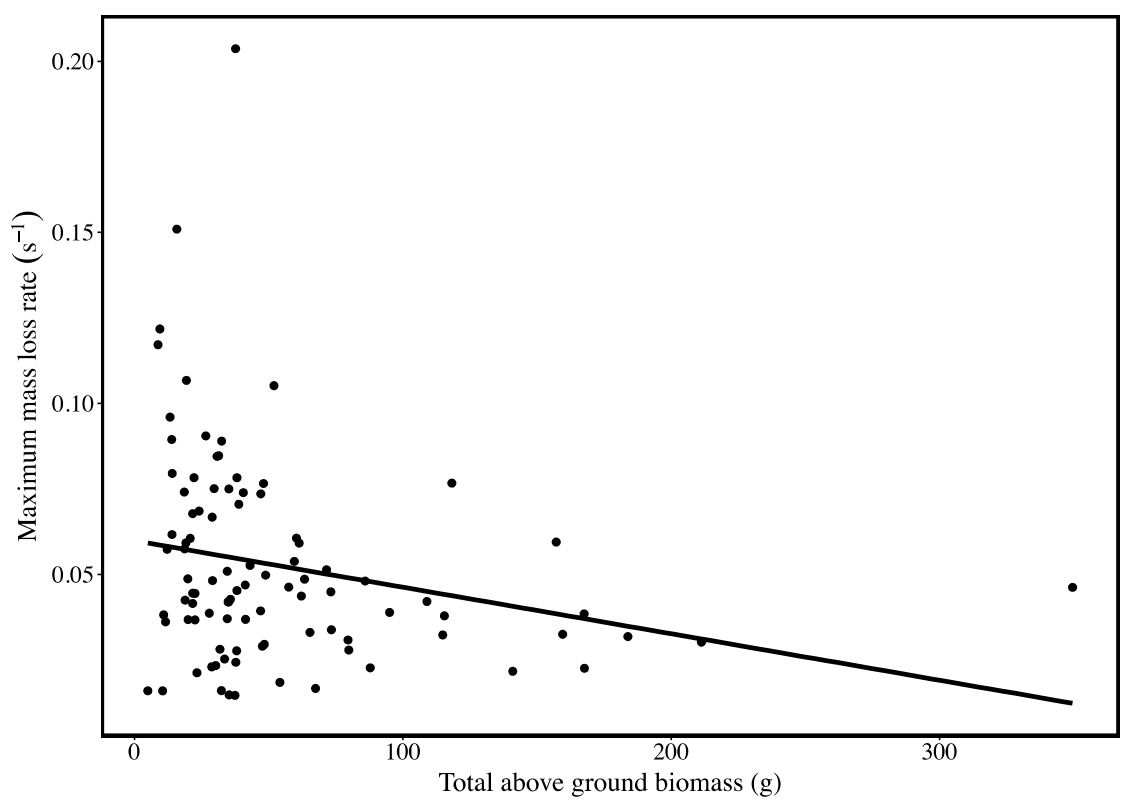

Figure 5. Relationship between total above-ground biomass and maximum mass-loss rate. Line indicates the best fit linear model ( $p=0.02$, adjusted $\left.R^{2}=0.044\right)$. 
Table 1. The contribution of biomass-height ratio, biomass density, and relative humidity to biomass-corrected flammability measurements as determined by linear mixed-effect models. Values in table represent model estimates of slopes and corresponding approximate $p$ values. All predictors were standardized to be mean-centered with unit standard deviation. Significant terms $(p<0.05)$ are in bold face. For detailed model results, see Supplementary Materials.

\begin{tabular}{|c|c|c|c|c|c|}
\hline & & Biomass-Height Ratio & Biomass Density $\left(\mathrm{g} \mathrm{cm}^{-3}\right)$ & Biomass-Height Ratio: Biomass Density * & Relative Humidity (\%) \\
\hline \multirow{2}{*}{ Temperature integration at $0 \mathrm{~cm}\left({ }^{\circ} \mathrm{C} \cdot \mathrm{s}\right)$} & Estimate & $-28,600$ & 12,500 & $-24,000$ & 11,500 \\
\hline & $p$ value & 0.038 & 0.194 & 0.081 & 0.071 \\
\hline \multirow{2}{*}{ Temperature integration at $25 \mathrm{~cm}\left({ }^{\circ} \mathrm{C} \cdot \mathrm{s}\right)$} & Estimate & -1910 & 2260 & 2880 & -2790 \\
\hline & $p$ value & 0.577 & 0.311 & 0.317 & 0.296 \\
\hline \multirow{2}{*}{ Max mass-loss rate $\left(\mathrm{s}^{-1}\right)$} & Estimate & 0.008 & -0.002 & -0.002 & 0.008 \\
\hline & $p$ value & 0.325 & 0.655 & 0.287 & 0.546 \\
\hline
\end{tabular}

Table 2. Mean \pm standard deviation of measured plant traits and flammability components of studied species. Shade tolerance information of each species was obtained from United States Department of Agriculture (USDA) plants database (https:/ / plants.usda.gov/java/).

\begin{tabular}{|c|c|c|c|c|c|c|c|}
\hline Species & Shade Tolerance & Total Mass (g) & Biomass-Height Ratio & $\begin{array}{l}\text { Biomass Density } \\
\left(\mathrm{g} \mathrm{cm}^{-3}\right)\end{array}$ & $\begin{array}{l}\text { Surface Temperature } \\
\text { Integration }\left({ }^{\circ} \mathrm{C} \cdot \mathrm{s}\right)\end{array}$ & $\begin{array}{l}\text { Canopy Temperature } \\
\text { Integration }\left({ }^{\circ} \mathrm{C} \cdot \mathrm{s}\right)\end{array}$ & $\begin{array}{l}\text { Max Mass-Loss } \\
\text { Rate }\left(\mathrm{s}^{-1}\right)\end{array}$ \\
\hline A. purpurea & Intolerant & $54.06 \pm 21.39$ & $0.86 \pm 0.16$ & $0.0040 \pm 0.0016$ & $184,750 \pm 118,090$ & $33,770 \pm 9303.3$ & $0.03 \pm 0.01$ \\
\hline B. inermis & Intolerant & $25.94 \pm 9.62$ & $1.46 \pm 0.24$ & $0.0019 \pm 0.0008$ & $34,145 \pm 21,426$ & $26,127 \pm 10,399$ & $0.05 \pm 0.02$ \\
\hline C. latifolium & Tolerant & $29.50 \pm 16.50$ & $5.46 \pm 0.64$ & $0.0007 \pm 0.0003$ & $9434 \pm 14,482$ & $19,072 \pm 10,061$ & $0.06 \pm 0.02$ \\
\hline E. curvula & Intolerant & $127.75 \pm 82.42$ & $1.78 \pm 0.42$ & $0.0019 \pm 0.0012$ & $196,100 \pm 155,930$ & $57,213 \pm 24,476$ & $0.05 \pm 0.02$ \\
\hline E. elymoides & Intolerant & $33.37 \pm 23.09$ & $1.69 \pm 0.55$ & $0.0032 \pm 0.0013$ & $67,199 \pm 90,330$ & $31,029 \pm 24,214$ & $0.05 \pm 0.03$ \\
\hline H. neomexicana & Intolerant & $74.06 \pm 40.20$ & $1.14 \pm 0.17$ & $0.0038 \pm 0.0019$ & $137,490 \pm 91,345$ & $54,096 \pm 26,103$ & $0.05 \pm 0.02$ \\
\hline P. anceps & Tolerant & $23.88 \pm 11.35$ & $3.04 \pm 0.10$ & $0.0007 \pm 0.0004$ & $13,742 \pm 49,547$ & $12,561 \pm 9814.1$ & $0.07 \pm 0.06$ \\
\hline P. smithii & Intolerant & $23.35 \pm 10.62$ & $1.39 \pm 0.10$ & $0.0026 \pm 0.0011$ & $34,626 \pm 38,135$ & $22,540 \pm 11,357$ & $0.06 \pm 0.04$ \\
\hline
\end{tabular}




\section{Discussion}

Total above-ground biomass positively influenced temperature exposure, which is consistent with previous grass flammability studies $[17,18]$. At identical low-fuel moisture content (average fuel moisture content: $5 \pm 0.005 \%$ ), grasses that accumulate more above-ground biomass will result in higher temperature exposure in plant tissues at both soil surface and at $25 \mathrm{~cm}$ above the ground.

Although total above-ground biomass had strong positive effects on cumulative temperature at different locations, biomass-height ratio had an additional negative effect on temperature integration at the soil surface. Larger biomass-height ratios indicated relatively less fuel near ground level and therefore less heat release at the soil surface, causing lower temperature integration above $100{ }^{\circ} \mathrm{C}$. Much of the variation we observe occurs at the species level-biomass-height ratio is relatively consistent within a species (Table 2). One species is an exception, however. C. califolium was variable in biomass-height ratio (range of 4-7), and the within-species pattern supports the overall pattern. Surface cumulative temperature predicts soil heating and meristem survival [53,54]. Biomass-height ratio has the potential to influence the ecological effects of fire. Vegetative recruitment via surface or below-ground meristems is an important reproduction method that contributes to the maintenance and dynamic of grasslands. Recurrent grass fires can stimulate vegetative reproduction in grasses by changing soil physical and chemical characteristics and increasing light availability while protecting meristems via a relatively low soil surface temperature $[3,4,55,56]$. However, increased temperature exposure in plant tissues at the soil surface, which is usually due to prolonged smoldering combustion, because this type of surface fire moves slowly yet with relatively high total heat release, still can suppress post-fire resprouting in grasses [53]. Grass-driven fire usually has a lower surface temperature and shorter fire residence time compared to other fuels [3], but grass mortality can occur at accumulated temperatures lower than many measured in our study. For example, mortality of Hesperostipa comata can occur after $3.4 \mathrm{~min}$ at $72{ }^{\circ} \mathrm{C}$ (equivalent to $14,688^{\circ} \mathrm{C} \cdot \mathrm{s}$ ) [57]. Increased fuel load, especially fuel load near ground, may push heat penetration into soil to surpass the lethal thermal threshold of surface and below-ground meristems in some species. The architectural effect we report demonstrates that even relatively low biomass species such as $A$. purpurea may cause tissue-killing soil heating if they have low biomass-height ratios.

Cumulative temperature at $25 \mathrm{~cm}$ was driven by total above-ground biomass alone. We expected that biomass-height ratio would increase canopy level heat release to cause higher temperature exposure, but we did not find any such effect. Canopy heating predicts post-fire woody species mortality by causing vascular cambium necrosis in bole and vegetative buds necrosis in the crown $[25,26,58]$. Although plant responses to crown or bole heating also depend on bark thickness and distribution of vegetative buds $[59,60]$, with more heat release resulting in higher temperature exposure in plant tissues, fires usually result in higher mortality rate [61,62]. Canopy heating may also contribute to xylem dysfunction, and this is another pathway of fire-induced tree mortality $[29,63,64]$. Although fuel load alone does positively affect cumulative temperature at $25 \mathrm{~cm}$, an increase in fuel load did not always lead to increased canopy temperature exposure in some species. We observed homogeneity in temperature exposure at $25 \mathrm{~cm}$ in our two largest studied species: E. curvula (mean total above-ground biomass $132.5 \mathrm{~g}$ ) and H. neomexicana (mean total above-ground biomass $74.1 \mathrm{~g}$ ) resulted in similar mean temperature integration and duration of heating above $100^{\circ} \mathrm{C}$ at $25 \mathrm{~cm}$ despite the difference in fuel load (Table 2). Such homogeneity also occurred in small-sized plants, for example, A. purpurea and E. elymoides. Because we did not find any weather effect on this flammability measurement, it is possible that some unexamined plant traits such as leaf chemistry had influence on temperature exposure at the canopy level. Canopy heating is largely determined by flaming combustion $[33,65]$. Flaming time, however, is negatively correlated with leaf nitrogen and phosphate concentration [66]. Tissue phosphate content also has a direct negative effect on total heat release during combustion by favoring char formation [12]. In addition, although leaf effective heat of combustion was a weaker predictor for grass flammability compared to fuel load, it negatively influenced flaming time at plant level [21]. 
We found a negative effect of fuel load on the rate of heat release without detecting any additional canopy architecture or humidity effects. In prior grass flammability studies, fuel load positively affected fire intensity, which was measured either by maximum combustion rate or by flame length [21,43]. The negative effect of fuel load on maximum biomass-loss rate, however, was mainly driven by the two largest species in our study and fuel load only explained $4 \%$ of the total variation (Figure 5). Most of the variation in maximum biomass-loss rate occurred across individuals and was pronounced among small plants (total mass $<50 \mathrm{~g}$, fuel density range: $0.0001 \mathrm{~g} \mathrm{~cm}^{-3}-0.002 \mathrm{~g} \mathrm{~cm}^{-3}$ ). The lack of relationship between rate of heat release and the measured traits, therefore, could result from the mass-loss readings of small-sized plants being more easily affected by air currents. Future improvement in measuring maximum biomass-loss rate is required.

In contrast with previous grass flammability studies, we examined canopy architecture effects by burning whole individuals rather than partial canopies. However, there are two shortcomings in our experiment. First, the two plant traits by which we characterized canopy architecture were correlated with one another with a correlation coefficient of -0.51 . Therefore, it is impossible to isolate the effects of biomass density and biomass-height ratio. Fill et al [43] found a positive effect of biomass density on smoldering time in Aristida stricta, which suggested that increase in biomass density could also lead to prolonged soil heating. Thus, the observed canopy architecture effect on temperature exposure at soil surface could result at least in part from interspecies variation in biomass density despite our model results favoring biomass-height ratio. The second potential shortcoming in our work is that we burned air-dried grasses to standardize fuel moisture content in order to better isolate canopy architecture affects. However, as one of the most important fuel traits, fuel moisture content dampens combustion by increasing the amount of energy required to preheat and dehydrate fuels [8]. Therefore, grasses with higher fuel moisture content will combust inefficiently, which would lead to prolonged smoldering combustion and produce smoke that can modify biomass density effects on aeration. Future work needs to determine what grass traits can affect fuel moisture content, which in turn will influence grass fire behavior. Some candidate grass traits include leaf dimension (which influences water absorption and loss [67]), fuel structure at the dormant stage (which influences water retention [68]), and phenology [69]).

A hypothesis to test in future work is that grass flammability varies between shade-tolerant and shade-intolerant species. Although fires can favor grasses by decreasing competition for light, in many woodlands and savannas, grass species show local habitat differentiation, with some species being restricted to open habitats and others persisting under tree canopies $[70,71]$. If enhanced flammability is beneficial to grasses because it leads to reduced tree-cover and decreases competition for light, we would expect the greatest benefit to shade-intolerant species. Thus, it is possible that shade tolerance and enhanced flammability are evolutionary correlated or that enhanced flammability is selected against in tree-associated grasses. Anecdotal evidence in support of this is that the two shade-tolerant species (data from USDA plants database) in our study were the two least flammable species (Table 2). In addition, top-heavy canopy architecture is associated with low light habitats: Elongated internodes place photosynthetic leaves higher into canopy to reach more light [72,73]. Moreover, grasses growing underneath tree canopies tend to have higher fuel moisture content relative to those persisting in open areas because of reduced solar radiation.

In fire-dependent savannas, hot and rapidly spreading grass fires suppress trees and favor grasses. Therefore, grass-fueled fire is a positive feedback that can lead to alternative stable states (either prairies or closed-canopy woodlands $[74,75])$. Researchers trying to understand such fire-mediated tree-grass interactions usually tend to treat grasses as homogenous fuels, and less attention has been paid to such interactions between different grasses and their woody competitors $[7,76]$. The observation that the tree-grass mix in savannas appears to be unstable due to positive feedback has prevented the explanation of long-term species composition stability [75,77]. The positive effect on soil heating by bottom-heavy biomass allocation pattern in grasses, however, may influence this positive vegetation-fire feedback on a fine scale depending on both post-fire recovery traits in trees and 
meristem allocation in grasses. For example, increased temperature exposure at soil surface could have greater impact on trees with thin bark and have a lesser impact on grasses with meristems protected underground. For such cases, low biomass-height ratio would strengthen the positive grass-fire feedback. On the other hand, for trees that survive fires mainly through aerial resprouting and are mostly susceptible to canopy heating, the effect we describe would have less impact. Our study highlights the need to include species-specific variation in flammability traits in the understanding of this process.

Supplementary Materials: The following are available online at http:/ /www.mdpi.com/2571-6255/1/3/35/ s1. Table S1. Mixed-effect model table for predictors of biomass-corrected temperature integration at soil surface. Approximate effective degrees of freedom, F-statistics, and $p$-values were calculated by Kenward-Roger approximation [49] using the "afex" package in R [48]. Table S2. Mixed-effect model coefficients for predictors of biomass-corrected temperature integration at soil surface. Results of linear mixed model fit with "lmer()" in the R package "lme4" [45]. All predictors were standardized to be mean-centered with unit standard deviation. Table S3. Mixed-effect model table for predictors of biomass-corrected temperature integration at $25 \mathrm{~cm}$. Approximate effective degrees of freedom, F-statistics, and $p$-values were calculated by Kenward-Roger approximation [49] using the "afex" package in R [48]. Table S4. Mixed-effect model coefficients for predictors of biomass-corrected temperature integration at $25 \mathrm{~cm}$. Results of linear mixed model fit with "lmer()"in the R package "lme4" [45]. All predictors were standardized to be mean-centered with unit standard deviation. Table S5. Mixed-effect model table for predictors of biomass-corrected maximum biomass-loss rate. Approximate effective degrees of freedom, F-statistics, and $p$-values were calculated by Kenward-Roger approximation [49] using the "afex" package in R [48]. Table S6. Mixed-effect model coefficients for predictors of biomass-corrected maximum biomass-loss rate. Results of linear mixed model fit with "lmer()"in the R package "lme4" (Bates et al. 2015). All predictors were standardized to be mean-centered with unit standard deviation.

Author Contributions: Each listed author contributed significantly to the completion of this work. Conceptualization, X.G. and D.E.S.; Methodology, X.G. and D.E.S.; Investigation, X.G.; Formal Analysis, X.G. and D.E.S.; Writing-Original Draft Preparation, X.G.; Writing-Review \& Editing, D.E.S.

Funding: Portion of this work benefited from funding from USGS South Central Climate Science Center to D.W.S.

Acknowledgments: We would like to thank all the staff at the Kiowa National Grassland and the Lyndon B. Johnson National Grassland for their logistical support. We thank the Lubbock Fire Department and, in particular, Chief Nick Wilson for giving us permission to the training house for performing our flammability experiments. We would also like to thank Kevin Price and Jonathan Galvez for their help in collecting all the plant materials. This work was in part supported by a South-Central Climate Science Grant to D.W.S.

Conflicts of Interest: The authors declare no conflict of interest.

\section{References}

1. Savadogo, P.; Zida, D.; Sawadogo, L.; Tiveau, D.; Tigabu, M.; Oden, P.C. Fuel and Fire Characteristics in Savanna-Woodland of West Africa in Relation to Grazing and Dominant Grass Type. Int. J. Remote Sens. 2007, 16, 531-539. [CrossRef]

2. Stocks, B.J.; Van Wilgen, B.W.; Trollope, W.S.W.; McRae, D.J.; Mason, J.A.; Weirich, F.; Potgieter, A.L.F. Fuels and Fire Behavior Dynamics on Large-Scale Savanna Fires in Kruger National Park, South Africa. J. Geophys. Res. 1996, 101, 23541-23550. [CrossRef]

3. Raison, R.J. Modification of the Soil Environment by Vegetation Fires, with Particular Reference to Nitrogen Transformations: A Review. Plant Soil 1979, 51, 73-108. [CrossRef]

4. Neary, D.G.; Klopatek, C.C.; Debano, L.F.; Ffolliott, P.F. Fire Effects on Belowground Sustainability: A Review and Synthesis. For. Ecol. Manag. 1999, 122, 51-71. [CrossRef]

5. Shackleton, C.M.; Scholes, R.J. Impact of Fire Frequency on Woody Community Structure and Soil Nutrients in the Kruger National Park. Koedoe 2000, 43, 75-81. [CrossRef]

6. Zida, D.; Sawadogo, L.; Tigabu, M.; Tiveau, D.; Ode, P.C. Dynamics of Sapling Population in Savanna Woodlands of Burkina Faso Subjected to Grazing, Early Fire and Selective Tree Cutting for a Decade. For. Ecol. Manag. 2007, 243, 102-115. [CrossRef]

7. D'Odorico, P.; Laio, F.; Ridolfi, L. A Probabilistic Analysis of Fire-Induced Tree-Grass Coexistence in Savannas. Am. Nat. 2006, 167, E79-E87. [CrossRef]

8. Rothermel, R.C. A Mathematical Model for Predicting Fire Spread in Wildland Fuels; USDA Forest Service Research Paper INT No. INT-115, 40; Intermountain Forest and Range Experiment Station: Ogden, UT, USA, 1972. 
9. Schwilk, D.W. Flammability Is a Niche Construction Trait: Canopy Architecture Affects Fire Intensity. Am. Nat. 2003, 162, 725-733. [CrossRef] [PubMed]

10. Jolly, W.M. Sensitivity of a Surface Fire Spread Model and Associated Fire Behavior Fuel Models to Changes in Live Fuel Moisture. Int. J. Wildl. Fire 2007, 16, 503-509. [CrossRef]

11. De Lillis, M.; Llusia, J.; Alessio, G.A.; Pen, J. Implications of Foliar Terpene Content and Hydration on Leaf Flammability of Quercus Ilex and Pinus Halepensis. Plant Biol. 2008, 10, 123-128. [CrossRef]

12. Scarff, F.; Westoby, M. The Influence of Tissue Phosphate on Plant Flammability: A Kinetic Study. Polym. Degrad. Stab. 2008, 93, 1930-1934. [CrossRef]

13. Paula, S.B.; Pausas, J.G.C.; Lloret, F.A. Fuel Loading and Flammability in the Mediterranean Basin Woody Species with Different Post-Fire Regenerative Strategies. Int. J. Wildl. Fire 2010, 19, 783-794. [CrossRef]

14. Baeza, M.J.; Santana, V.M.; Pausas, J.G.; Vallejo, V.R. Successional Trends in Standing Dead Biomass in Mediterranean Basin Species. J. Veg. Sci. 2011, 22, 467-474. [CrossRef]

15. Page, W.G.; Jenkins, M.J.; Runyon, J.B. Mountain Pine Beetle Attack Alters the Chemistry and Flammability of Lodgepole Pine Foliage. Can. J. For. Res. 2012, 42, 1631-1647. [CrossRef]

16. Scarff, F.; Gray, B.; Westoby, M. Exploring Phosphate Effects on Leaf Flammability Using a Physical Chemistry Model. Int. J. Wildl. Fire 2012, 21, 1042-1051. [CrossRef]

17. Setterfield, S.A.; Rossiter, N.A.; Hutley, L.B.; Douglas, M.M.; Williams, R.J. Turning up the Heat: The Impacts of Andropogon gayanus (Gamba Grass) Invasion on Fire Behaviour in Northern Australian Savannas. Divers. Distrib. 2010, 16, 854-861. [CrossRef]

18. Rossiter, N.A.; Setterfield, S.A.; Douglas, M.M.; Hutley, L.B. Testing the Grass-Fire Cycle: Alien Grass Invasion in the Tropical Savannas of Northern Australia. Divers. Distrib. 2003, 9, 169-176. [CrossRef]

19. Hughes, F.; Vitousek, P.M.; Tunison, T. Alien Grass Invasion and Fire in the Seasonal Submontane Zone of Hawai. Ecology 1991, 72, 743-746. [CrossRef]

20. Ripley, B.; Donald, G.; Osborne, C.P.; Abraham, T.; Martin, T. Experimental Investigation of Fire Ecology in the C3 and C4 Subspecies of Alloteropsis semialata. J. Ecol. 2010, 98, 1196-1203. [CrossRef]

21. Simpson, K.J.; Ripley, B.S.; Christin, P.A.; Belcher, C.M.; Lehmann, C.E.R.; Thomas, G.H.; Osborne, C.P. Determinants of Flammability in Savanna Grass Species. J. Ecol. 2016, 104, 138-148. [CrossRef] [PubMed]

22. Swezy, D.M.; Agee, J.K. Prescribed-Fire Effect on Fine Root and Tree Mortality in Old-Growth Ponderosa Pine. Can. J. For. Res. 1991, 21, 626-634. [CrossRef]

23. Monsanto, P.G.; Agee, J.K. Long-Term Post-Wildfire Dynamics of Coarse Woody Debris after Salvage Logging and Implications for Soil Heating in Dry Forests of the Eastern. For. Ecol. Manag. 2008, 255, 3952-3961. [CrossRef]

24. Sieg, C.H.; McMillin, J.D.; Fowler, J.F.; Allen, K.K.; Negron, J.F.; Wadleigh, L.L.; Anhold, J.A.; Gibson, K.E. Best Predictors for Postflre Mortality of Ponderosa Pine Trees in the Intermountain West. For. Sci. 2006, 52, 718-728.

25. Ryan, K.C.; Peterson, D.L.; Reinhardt, E.D. Modeling Long-Term Fire-Caused Mortality of Douglas-Fir. For. Sci. 1988, 34, 190-199.

26. Stephens, S.L.; Finney, M.A. Prescribed Fire Mortality of Sierra Nevada Mixed Conifer Tree Species: Effects of Crown Damage and Forest Floor Combustion. For. Ecol. Manag. 2002, 162, 261-271. [CrossRef]

27. Andreas, B.; Nardini, A.; Mayr, S. Post-Fire Effects in Xylem Hydraulics of Picea abies, Pinus sylvestris and Fagus sylvatica. New Phytol. 2018, 217, 1484-1493. [CrossRef]

28. Michaletz, S.T.; Johnson, E.A.; Tyree, M.T. Moving beyond the Cambium Necrosis Hypothesis of Post-Fire Tree Mortality: Cavitation and Deformation of Xylem in Forest Fires. New Phytol. 2012, 194, 254-263. [CrossRef] [PubMed]

29. West, A.G.; Nel, J.A.; Bond, W.J.; Midgley, J.J. Experimental Evidence for Heat Plume-Induced Cavitation and Xylem Deformation as a Mechanism of Rapid Post-Fire Tree Mortality. New Phytol. 2016, 211, 828-838. [CrossRef] [PubMed]

30. Hély, C.; Flannigan, M.D.; Bergeron, Y. Modeling Tree Mortality Following Wildfire in the Southeastern Canadian Mixed-Wood Boreal Forest. For. Sci. 2003, 49, 566-576.

31. Alexander, M.E.; Cruz, M.G. Interdependencies between Flame Length and Fireline Intensity in Predicting Crown Fire Initiation and Crown Scorch Height. Int. J. Wildl. Fire 2012, 21, 95-113. [CrossRef]

32. Ryan, K.C.; Frandsen, W.H. Basal Injury from Smoldering Sires in Mature Pinus Ponderosa Laws. Int. J. Wildl. Fire 1991, 1, 107-118. [CrossRef] 
33. Bova, A.S.; Dickinson, M.B. Linking Surface-Fire Behavior, Stem Heating, and Tissue Necrosis. Can. J. For. Res. 2005, 35, 814-822. [CrossRef]

34. Busse, M.D.; Hubbert, K.R.; Fiddler, G.O.; Shestak, C.J.; Powers, R.F. Lethal Soil Temperatures during Burning of Masticated Forest Residues. Int. J. Wildl. Fire 2005, 14, 267-276. [CrossRef]

35. Schwilk, D.W. Dimensions of Plant Flammability. New Phytol. 2015, 206, 486-488. [CrossRef] [PubMed]

36. Pausas, J.G.; Keeley, J.E.; Schwilk, D.W. Flammability as an Ecological and Evolutionary Driver. J. Ecol. 2017, 105, 289-297. [CrossRef]

37. De Magalhães, R.M.Q.; Schwilk, D.W. Leaf Traits and Litter Flammability: Evidence for Non-Additive Mixture Effects in a Temperate Forest. J. Ecol. 2012, 100, 1153-1163. [CrossRef]

38. Cornwell, W.K.; Elvira, A.; van Kempen, L.; van Logtestijn, R.S.P.; Aptroot, A.; Cornelissen, J.H.C. Flammability across the Gymnosperm Phylogeny: The Importance of Litter Particle Size. New Phytol. 2015, 206, 672-681. [CrossRef] [PubMed]

39. Engber, E.A.; Varner, J.M. Patterns of Flammability of the California Oaks: The Role of Leaf Traits. Can. J. For. Res. 2012, 42, 1965-1975. [CrossRef]

40. Cruz, M.G.; Alexander, M.E.; Wakimoto, R.H. Development and Testing of Models for Predicting Crown Fire Rate of Spread in Conifer Forest Stands. Can. J. For. Res. 2005, 35, 1626-1639. [CrossRef]

41. Cassandra, V.A.; van Logtestijn, R.; Cornwell, W.; Cornelissen, H. Species Composition and Fire: Non-Additive Mixture Effects on Ground Fuel Flammability. Front. Plant Sci. 2012, 3, 1-10. [CrossRef] [PubMed]

42. Martin, R.; Gordon, D.; Gutierrez, M.; Lee, D.; Molina, D.; Schroeder, R.; Sapsis, D.; Stephens, S.; Chambers, M. Assessing the Flammability of Domestic and Wildland Vegetation. In Proceedings of the 12th Conference on Fire and Forest Meteorology, Jekyll Island, GA, USA, 26-28 October 1993.

43. Fill, J.M.; Moule, B.M.; Varner, J.M.; Mousseau, T.A. Flammability of the Keystone Savanna Bunchgrass Aristida Stricta. Plant Ecol. 2016, 217, 331-342. [CrossRef]

44. R Core Team. R: A Language and Environment for Statistical Computing; R Foundation for Statistical Computing: Vienna, Austria, 2017. Available online: https:/ / www.R-project.org/ (accessed on 30 November 2017).

45. Bowman, D.M.J.S.; Wilson, B.A. Fuel Characteristics of Coastal Monsoon Forests, Northern Territory, Australia. J. Biogeogr. 1988, 15, 807-817. [CrossRef]

46. Britton, C.M.; Dodd, J.D.; Weichert, A.T. Energy Values of Plant Species and Litter of an AndropogonPaspalum Grassland. J. Biogeogr. 1976, 3, 389-395. [CrossRef]

47. Bates, D.; Maechler, M.; Bolker, B.; Walker, S. Fitting Linear Mixed-Effects Models Using Lme4. J. Stat. Softw. 2015, 67, 1-48. [CrossRef]

48. Zuur, A.F.; Ieno, E.N.; Walker, N.J.; Saveliev, A.A.; Smith, G.M. Mixed Effects Modelling for Nested Data. In Mixed Effects Models and Extensions in Ecology with R; Springer: New York, NY, USA, 2009; pp. 127-128.

49. Akaike, H. Information Theory and an Extension of the Maximum Likelihood Principle. In Selected Papers of Hirotugu Akaike; Springer: New York, NY, USA, 1998; pp. 199-213.

50. Singmann, H.; Bolker, B.; Westfall, J.; Aust, F. Afex: Analysis of Factorial Experiments. Version 0.19-1. 2018. Available online: https: / CRAN.R-project.org/package=afex (accessed on 8 March 2018).

51. Kenward, M.G.; Roger, J.H. Small Sample Inference for Fixed Effects from Restricted Maximum Likelihood. Biometrics 1997, 53, 983-997. [CrossRef] [PubMed]

52. Luke, S.G. Evaluating Significance in Linear Mixed-Effects Models in R. Behav. Res. Methods 2017, 49, 1494-1502. [CrossRef] [PubMed]

53. Odion, D.C.; Davis, F.W. Fire, Soil Heating, and the Formation of Vegetation Patterns in Chaparral. Ecol. Monogr. 2000, 70, 149-169. [CrossRef]

54. Reinhardt, E.D. Using FOFEM 5.0 to Estimate Tree Mortality, Fuel Consumption, Smoke Production and Soil Heating from Wildland Fire. In Proceedings of the 2nd International Wildland Fire Ecology and Fire Management Congress and 5th Symposium on Fire and Forest Meteorology, Orlando, FL, USA, 16-20 November 2003; pp. 16-20.

55. Sharrow, S.H.; Wright, H.A. Effects of Fire, Ash, and Litter on Soil Nitrate, Temperature, Moisture and Tobosagrass Production in the Rolling Plains. Soc. Range Manag. 1977, 30, 266-270. [CrossRef]

56. Hulbert, L.C. Causes of Fire Effects in Tallgrass Prairie. Ecology 1988, 69, 46-58. [CrossRef]

57. Wright, H.A. A Method to Determine Heat-Caused Mortality in Bunchgrasses. Ecology 1970, 51, 582-587. [CrossRef] 
58. Catry, F.X.; Rego, F.; Moreira, F.; Fernandes, P.M.; Pausas, J.G. Post-Fire Tree Mortality in Mixed Forests of Central Portugal. For. Ecol. Manag. 2010, 260, 1184-1192. [CrossRef]

59. Clarke, P.J.; Lawes, M.J.; Midgley, J.J.; Lamont, B.B.; Ojeda, F.; Burrows, G.E.; Enright, N.J.; Knox, K.J.E. Resprouting as a Key Functional Trait: How Buds, Protection and Resources Drive Persistence after Fire. New Phytol. 2013, 197, 19-35. [CrossRef] [PubMed]

60. Lawes, M.J.; Adie, H.; Russell-Smith, J.; Murphy, B.; Midgley, J.J. How Do Small Savanna Trees Avoid Stem Mortality by Fire? The Roles of Stem Diameter, Height and Bark Thickness. Ecosphere 2011, 2, art42. [CrossRef]

61. Bowman, D.M.J.S.; Haverkamp, C.; Rann, K.D.; Prior, L.D. Differential Demographic Filtering by Surface Fires: How Fuel Type and Fuel Load Affect Sapling Mortality of an Obligate Seeder Savanna Tree. J. Ecol. 2017, 106, 1-13. [CrossRef]

62. Stephens, S.L.; Moghaddas, J.J. Experimental Fuel Treatment Impacts on Forest Structure, Potential Fire Behavior, and Predicted Tree Mortality in a California Mixed Conifer Forest. For. Ecol. Manag. 2005, 215, 21-36. [CrossRef]

63. Balfour, D.A.; Midgley, J.J. Fire Induced Stem Death in an African Acacia Is Not Caused by Canopy Scorching. Austral Ecol. 2006, 31, 892-896. [CrossRef]

64. Michaletz, S.T. Xylem Dysfunction in Fires: Towards a Hydraulic Theory of Plant Responses to Multiple Disturbance Stressors. New Phytol. 2018, 217, 1391-1393. [CrossRef] [PubMed]

65. Dickinson, M.B. Heat Transfer and Vascular Cambium Necrosis in the Boles of Trees during Surface Fires. In Forest Fire Research \& Wildland Fire Safety; Viegas, D.X., Ed.; Millpress: Rotterdam, The Netherlands, 2002.

66. Grootemaat, S.; Wright, I.J.; Van Bodegom, P.M.; Cornelissen, J.H.C.; Cornwell, W.K. Burn or Rot: Leaf Traits Explain Why Flammability and Decomposability Are Decoupled across Species. Funct. Ecol. 2015, 29, 1486-1497. [CrossRef]

67. Matthews, S. A Process-Based Model of Fine Fuel Moisture. Int. J. Wildl. Fire 2006, 15, 155-168. [CrossRef]

68. Wotton, B.M. A Grass Moisture Model for the Canadian Forest Fire Danger Rating System. In Proceedings of the 8th Symposium on Fire and Forest Meteorology, Kalispell, MT, USA, 13-15 October 2009.

69. Kidnie, S.; Cruz, M.G.; Gould, J.S.; Nichols, D.; Bessell, R.; Slijepcevic, A. Effects of Curing on Grassfires: II. Effect of Grass Senescence on the Rate of Fire Spread. Int. J. Wildl. Fire 2015, 24, 828-837. [CrossRef]

70. Whittaker, R.H.; Gilbert, L.E.; Connell, J.H. Analysis of Two-Phase Pattern in a Mesquite Grassland, Texas. J. Ecol. 1979, 67, 935-952. [CrossRef]

71. Weltzin, J.F.; Coughenour, M.B. Savanna Tree Influence on Understory Vegetation and Soil Nutrients in Northwestern Kenya. J. Veg. Sci. 1990, 1, 325-332. [CrossRef]

72. Collins, B.; Wein, G. Stem Elongation Response to Neighbour Shade in Sprawling and Upright Polygonum Species. Ann. Bot. 2000, 86, 739-744. [CrossRef]

73. Sasidharan, R.; Chinnappa, C.C.; Voesenek, L.A.C.J.; Pierik, R. The Regulation of Cell Wall Extensibility during Shade Avoidance: A Study Using Two Contrasting Ecotypes. Plant Physiol. 2008, 148, 1557-1569. [CrossRef] [PubMed]

74. Scholes, R.J.; Archer, S.R. Tree-Grass Interactions in Savannas. Annu. Rev. Ecol. Systemat. 1997, $28,517-544$. [CrossRef]

75. Van Langevelde, F.; van de Vijver, C.A.D.M.; Kumar, L.; van de Koppel, J.; de Ridder, N.; van Andel, J.; Skidmore, A.K.; Hearne, J.W.; Stroosnijder, L.; Bond, W.J.; et al. Effects of Fire and Herbivory on the Stability of Savanna Ecosystems. Ecology 2003, 84, 337-350. [CrossRef]

76. Menaut, J.C.; Gignoux, J.; Prado, C.; Clobert, J. Tree Community Dynamics in a Humid Savanna of the Cote-d'Ivoire: Modelling the Effects of Fire and Competition with Grass and Neighbours. J. Biogeogr. 1990, 17, 471-481. [CrossRef]

77. Beckage, B.; Platt, W.J.; Gross, L.J. Vegetation, Fire, and Feedbacks: A Disturbance-Mediated Model of Savannas. Am. Nat. 2009, 174, 805-818. [CrossRef] [PubMed]

(C) 2018 by the authors. Licensee MDPI, Basel, Switzerland. This article is an open access article distributed under the terms and conditions of the Creative Commons Attribution (CC BY) license (http:// creativecommons.org/licenses/by/4.0/). 